\title{
Training of the specialist in critical medicine
}

\section{La formación del especialista en medicina crítica}

\author{
Jorge A. Castañón-González, “ Luis A. Gorordo-Delsol, Jessica Garduño-López, \\ Marcos A. Amezcua-Gutiérrez and María de los A. Espino-Ángeles \\ Secretaría de Salud, Hospital Juárez de México, Adult Intensive Care Unit, Mexico City, Mexico
}

The vertiginous expansion of knowledge in all areas (technology, organization, education, research, administration, health services' financing, etc.) affects health professionals education and training, ${ }^{1}$ which has resulted in medical specialties and subspecialties no longer being only classified according to the traditional form by organs and systems (neurology, nephrology, etc.), but also by the attention they pay to age (pediatrics, geriatrics) and gender groups (gynecology \& obstetrics), to the type of conditions (infectology, oncology), the setting (anesthesiology, emergency medicine), type of procedure (colon and rectum surgery, neurophysiology, neurological surgery), level of care (primary or secondary care), or according to their horizontal (critical medicine, family medicine) or vertical structure, such as core specialties (internal medicine, general surgery) ${ }^{2}$ (Figs. 1, 2 and 3).

Currently, hospital medical care is provided in the form of multidisciplinary collaboration, where intervention of the specialist or subspecialist is occasional, selective and generally for short and intermittent periods; participation of other health professionals who have different but complementary training is required. To deal with the shortage of specialists (for which a short-term solution is not envisioned), some specialties, particularly critical medicine, compensate it in two forms:

- Acquisition of technical skills that were exclusive to other specialties, such as ultrasound to guide procedures, to perform neurological, hemodynamic and respiratory evaluation; bronchoscopies, renal replacement therapy, etc.
- Generation of mixed postgraduate training programs such as trauma-surgery and intensive care, trauma-anesthesia and intensive care, intensive coronary care, pulmonology-critical medicine.

Both solutions have gained ground and proven effective in other countries, the former particularly in Europe and the latter in the United States, where sufficient economic and technical resources are available for each specialty to carry out its own procedures.

In Mexico, most critical medicine schools, including those the authors graduated from, have leaned toward the first solution,,$^{3-7}$ due to economic difficulties to finance the number of places required for postgraduate mixed courses and difficulties to reach agreements with the 47 medical specialty boards grouped in the Medical Specialty Boards National Regulatory Committee (Conacem - Comité Normativo Nacional de Consejos de Especialidades Médicas); of note, in the United States there are only 24 boards.

Acquiring and sharing technical skills that are exclusive to other specialties can be an alternative to compensate and complement the number of specialist physician positions in the mid-term without increasing the number of specialty boards, unless this is strictly necessary. This approach has been so successful that many core specialization programs such as emergency medicine, internal medicine, general surgery, anesthesiology and now also obstetrics \& gynecology, cardiology, neurology and pulmonology, among others, perform clinical rotations or training in intensive care units.

Given that the intensive care unit is the place in modern hospitals where the largest number of surgical procedures
Correspondence:

*Jorge A. Castañón-González

E-mail: jorge.castanong @ gmail.com

0016-3813/@ 2019 Academia Nacional de Medicina de México, A.C.. Published by Permanyer. This is an open access article under the CC BY-NC-ND
Gac Med Mex. 2020;156:1-3

Contents available at PubMed

www.gacetamedicademexico.com

Date of acceptance: 11-12-2019 


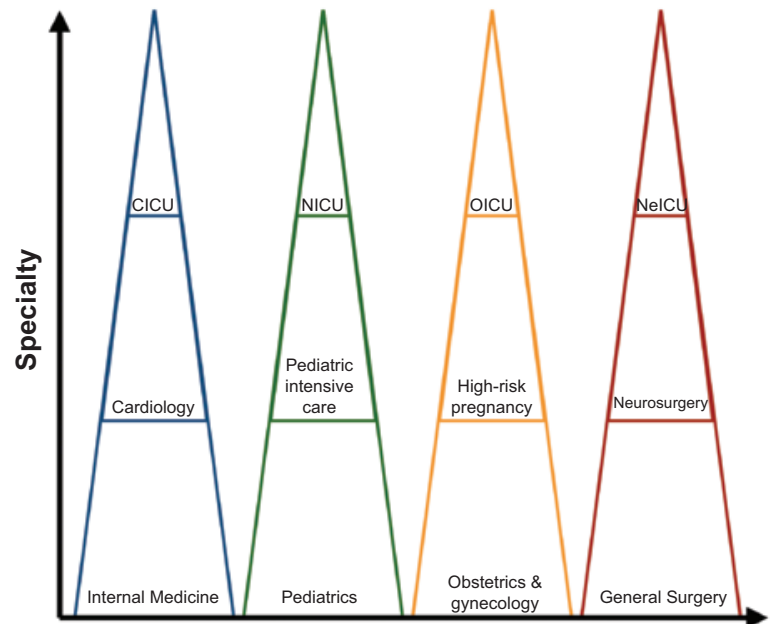

Field of action

Figure 1. Vertical (traditional) arrangement of specialties and subspecialties in medicine. $\mathrm{ClCU}=$ Cardiovascular Intensive Care Unit, $\mathrm{NICU}=$ Neonatal Intensive Care Unit, OICU = Obstetric Intensive Care Unit, NeICU = Neurointensive Care Unit.

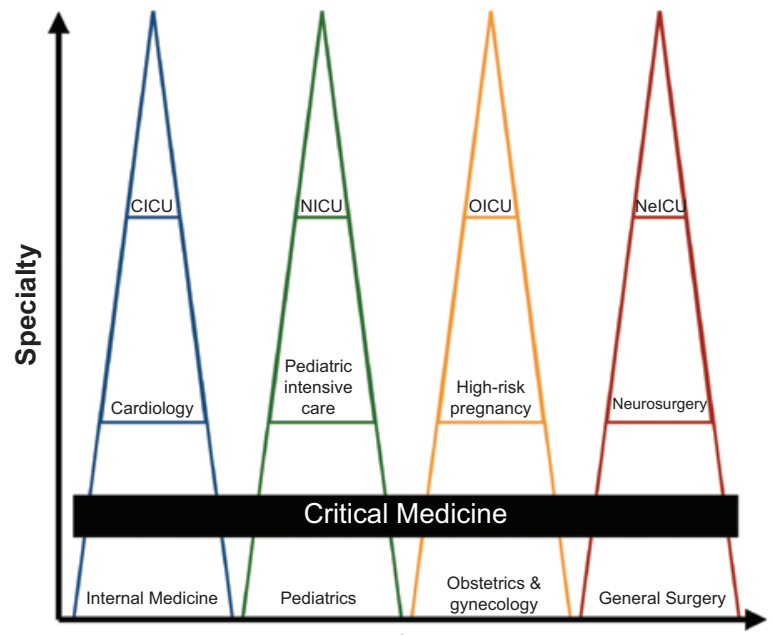

Field of action

Figure 2. Horizontal arrangement of the critical medicine specialty in a general hospital.

are carried out after the operating room, the benefits of these approaches in terms of skill acquisition have not been slow in coming, since critical medicine has brought diagnostic modalities such as ultrasound to patient bedside, which has added a "fifth" element to classical physical examination: insonation is added to inspection, palpation, percussion and auscultation. ${ }^{8,9}$ Furthermore, bronchoscopy is currently considered essential for difficult tracheal intubations, aspiration of secretions, resolution of atelectasis and bronchoalveolar lavage sampling for microbiological analysis in lower respiratory infections.

The evolution of critical medicine has allowed the comprehensive care of the seriously and critically ill patient in an expedited and continuous manner 24 hours

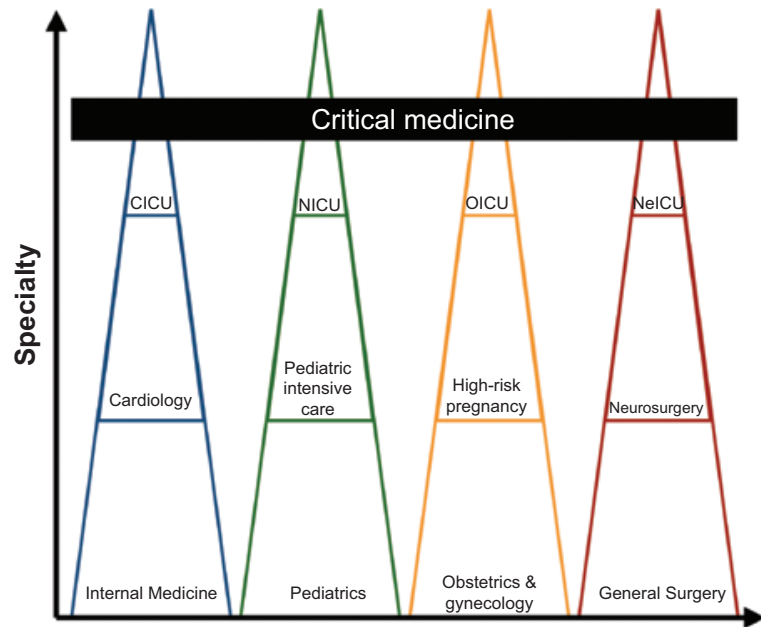

Field of action

Figure 3. Horizontal arrangement of the critical medicine specialty in a specialty hospital.

a day and seven days a week; moreover, it has helped to establish diagnoses, to hierarchically organize and prioritize relevant consultations and for treatment to be provided in an early and efficient form and at lower cost by decreasing intensive care unit length of stay.

Mexico is a developing country where cutting-edge technology lacks a homogeneous distribution across the national territory, which makes for it not to be within reach for everyone. In addition, Mexico is a country where the intensive care unit bed-day cost is exorbitant due to the country's dependence on foreign technology: in 2018 it was established at $\$ 35,400$ Mexican pesos, which is the most expensive unit concept in the tabulator after surgery. ${ }^{10}$ Fortunately, Mexico is also a nation where pressures exerted by society and its official bodies curb the increasing cost of medical care, still largely regulated by our profession, and it is thus the responsibility of critical medicine specialists to make a deep and careful reflection on the cost-benefit of our practice in order to optimize resources, which are limited in the face of a demand for services that is exponentially increasing.

It is important to explain resident physicians that clinical observations based on adequate propedeutics, semiology and clinical context recognition are fundamental and will be complemented by imaging studies, but it is the doctor who must confer them their clinical value for their application. The principle of William of Ockam, a $13^{\text {th }}$ century scholastic philosopher ("Entia non sunt multiplicanda praeter necessitatem"), says that entities should not be multiplied beyond necessity or, in other words, that it is futile to do with more what can be done with fewer. 
It is important to reiterate this principle of logical and common sense analysis to resident physicians, since it is often lost in the educational process and is likely to be deliberately destroyed in the political process. We believe that, even in ideal working conditions, the critical medicine specialist should be austere at his/her clinical practice by conviction in and not by necessity or institutional fashion, and always base his/her decisions on solid clinical propedeutics, broad knowledge on the subject and supported by the most up-to-date scientific evidence. ${ }^{11}$

\section{References}

1. Ruelas-Barajas E, Alonso-Concheiro A, Alarcón-Fuentes A. Las especialidades. En: Consejo de Salubridad General, Secretaría de Salud, Academia Nacional de Medicina, editores. Futuros de la formación de recursos humanos para la salud en México 2005-2050. México: Ediciones Láser; 2008. pp. 53-58.

2. Castañón-González JA, Macías-Hernández AE, Polanco-González C Domínguez-Cherit G. Broadening the scope of health care personnel in Critical Care Medicine. Cir Cir. 2011;79:451-452.
3. Ángeles-Valdés J, Bucay-Chouchleb M, Castañón-González JA, Fuentes-Pintado E. Ecocardiografía transesofágica en la unidad de cuidados intensivos. Rev Asoc Mex Med Crit Ter Intensiva. 1993;7(2):70-73.

4. Ángeles-Valdés J, Castañón-González JA, Bucay-Chouchleb M, Miranda-Ruíz R, Gómez-Velázquez AG. Utilidad de la ecocardiografía en la unidad de cuidados intensivos. Rev Asoc Mex Med Crit Ter Intensiva. 1993;7(5):172-177.

5. Deseáno-Estudillo JL, Castañón-González JA, Carbajal-Ramírez A, Castrejón-Román H, León-Gutiérrez MA. Espectro de velocidad del flujo sanguíneo cerebral por ultrasonido Doppler transcraneal en pacientes con criterios clínicos de muerte cerebral. Gac Med Mex. 2003;139:535-538.

6. Briones JC, Castañón JA, Díaz de León M, Briones CG. Velocidad de flujo sanguíneo cerebral en la preeclampsia-eclampsia. Prog Ostet Ginecol. (España) 2000;43:511-520.

7. Castañón-González JA, Castillo-Rodríguez G, Janet Tanus-Haij J, Valencia-Jiménez E. Colecistitis aguda acalculosa en una unidad de cuidados intensivos multidisciplinaria. Gac Med Mex. 1996:131:469-475.

8. Gómez-López L, Torres B, Bergé R, Aguirre O, Luis M, Sala-Blanch X. Medición ecográfica de parámetros anatómicos de la vía aérea superior en adultos. Rev Esp Anestesiol Reanim. 2018;65:495-503.

9. Pestana L. Insonar: cuestión de ángulos. Panace@ 2001;2(3). www. medtrad.org/panacea/Indice. Consultado el 02/febrero/2019.

10. Aprobación de los costos unitarios por nivel de atención médica actualizados al año 2018. Acuerdo ACDO.AS3.HCT.291117/275.P.DF del 29 de noviembre de 2018. Diario Oficial 2017 Dic 28.

11. Castañón-González JA. Reflexiones sobre la aplicación clínica de la tecnología en medicina crítica. Rev Asoc Mex Med Crit Ter Intensiva. 1994:8:40-41. 